Supporting Information

\title{
Synthesis and Characterization of Dithia[3.3](2,6)pyridinophane-Containing Polymers: Application to the Palladium-Catalyzed Heck Reaction
}

\author{
Yasuhiro Morisaki, Tamao Ishida, and Yoshiki Chujo* \\ Department of Polymer Chemistry, Graduate School of Engineering, Kyoto University, \\ Katsura, Nishikyo-ku, Kyoto 615-8510, Japan \\ chujo@chujo.synchem.kyoto-u.ac.jp
}




\section{General}

${ }^{1} \mathrm{H}$ and ${ }^{13} \mathrm{C}$ NMR spectra were recorded on a JEOL EX400 spectrometer at 400 and 100 $\mathrm{MHz}$, respectively. The chemical shift values were expressed relative to $\mathrm{Me}_{4} \mathrm{Si}$ as an internal standard. IR spectra were obtained on a Perkin-Elmer 1600 spectrometer. Gel permeation chromatography was carried out on a TOSOH UV-8020 and RI-8020 (TSK gel $\alpha$-3000 column) using $\mathrm{CHCl}_{3}$ as an eluent after calibration with standard polystyrene. GLC analyses were performed on a Shimadzu GC-17A gas chromatograph with a capillary column (Shimadzu capillary column HiCap-CBP10M25-025: $0.22 \mathrm{~mm}$ i.d. $\mathrm{x} 25 \mathrm{~m}$ ) using $n$-pentadecane as an internal standard. Analytical thin-layer chromatography (TLC) was performed with silica gel 60 Merck $\mathrm{F}_{254}$ plates. Column chromatography was performed with Wakogel C-300 silica gel. Elemental analyses were performed at the Microanalytical Center of Kyoto University.

\section{Materials}

Toluene and $\mathrm{CH}_{2} \mathrm{Cl}_{2}$ were distilled from $\mathrm{CaH}_{2} . \quad i-\mathrm{Pr}_{2} \mathrm{NH}$ and $\mathrm{NEt}_{3}$ were distilled from $\mathrm{KOH}$. Dehydrated grade of methanol, ethanol, DMF, and benzene were purchased and used without further purification. Chelidamic acid monohydrate $1, \mathrm{PBr}_{3}, \mathrm{HBr}(30 \%$ in acetic acid), $\mathrm{NaBH}_{4}, \mathrm{NaOH}, \mathrm{CuI}$, thiourea, $\mathrm{PdCl}_{2}\left(\mathrm{PPh}_{3}\right)_{2}$, tricyclohexylphosphine $\left(\mathrm{PCy}_{3}\right)$ (15\% in toluene solution), phenyl iodide, 4-methoxyphenyl iodide, 4-nitrophenyl bromide, $t$-butyl acrylate, methyl acrylate, methyl methacrylate, styrene, $\mathrm{PdCl}_{2}(\mathrm{PhCN})_{2}$, and (2,2'-bipyridine)dichloropalladium 12 were obtained commercially, and used without further purification. 2,6-Bis(bromomethyl)-4-bromopyridine 4 was prepared from chelidamic acid monohydrate 1 according to the published procedure. ${ }^{1}$ 2,6Bis(isothiouroniummethyl)-4-bromopyridine dibromide $\mathbf{5}^{2}$ and 6,15-dibromo-2,11dithia[3.3](2.6)pyridinophane $7^{2}$ were prepared by referring to the literature with minor modification. 
to the published procedure. All of the new compounds are characterized below.

2,6-Bis(isothiouroniummethyl)-4-bromopyridine dibromide 5. A mixture of 2,6bis(bromomethyl)-4-bromopyridine 4 (2.70 g, $7.86 \mathrm{mmol})$, and thiourea (1.32 g, 17.4 mmol) was placed in a $50 \mathrm{~mL}$ Pyrex flask equipped with a magnetic stirring bar under a flow of nitrogen. Dehydrated ethanol $(18 \mathrm{~mL})$ was added, and the reaction mixture was refluxed for 2 hours with stirring. After cooling, the white solid was precipitated. The product was separated by filtration, washed with ethanol, and dried in vacuo to give 2,6-bis(isothiouroniummethyl)-4-bromopyridine dibromide 5 (3.54 g, 7.14 mmol, 91\%) as a white solid. ${ }^{1} \mathrm{H}$ NMR (DMSO- $\left.d_{6}, 400 \mathrm{MHz}\right): \delta 4.63(\mathrm{~s}, 4 \mathrm{H}), 7.81(\mathrm{~s}, 2 \mathrm{H}), 9.08$ (brs, 4H), 9.34 (brs, $4 \mathrm{H}$ ); ${ }^{13} \mathrm{C}$ NMR (DMSO- $d_{6}, 100 \mathrm{MHz}$ ): $\delta 35.3,125.7,134.0,156.8$, 169.3. Anal. Calcd. for $\mathrm{C}_{9} \mathrm{H}_{14} \mathrm{Br}_{3} \mathrm{~N}_{5} \mathrm{~S}_{2}$ : C 21.79; H 2.84. Found: C 22.02; H 2.69.

6,15-Dibromo-2,11-dithia[3.3](2.6)pyridinophane 7. To a solution of 5 (3.13 g, 6.31 mmol) in $110 \mathrm{~mL}$ of dehydrated methanol was added $\mathrm{NaBH}_{4}(0.985 \mathrm{~g}, 26.0 \mathrm{mmol})$ slowly with vigorous stirring to generate thiol. This solution and a solution of $\mathbf{4}$ (2.20 $\mathrm{g}, 6.40 \mathrm{mmol})$ in $110 \mathrm{~mL}$ of ethanol-benzene (7:4) were added dropwise simultaneously to a boiling solution of $\mathrm{NaOH}(0.707 \mathrm{~g}, 17.6 \mathrm{mmol})$ in $100 \mathrm{~mL}$ of dehydrated ethanol. After the complete addition ( $24 \mathrm{~h})$, the solution was refluxed for additional 24 hours. The reaction mixture was allowed to cool to room temperature and concentrated. The residue was dissolved in $\mathrm{CHCl}_{3}$. The organic layer was washed with $1 \mathrm{~N} \mathrm{HCl}$, water, and dried over $\mathrm{Na}_{2} \mathrm{SO}_{4}$. The solvent was removed under reduced pressure, and the crude product was subjected to column chromatography on $\mathrm{SiO}_{2}$ with $\mathrm{CHCl}_{3}$ as an eluent to give 6,15-dibromo-2,11-dithia[3.3](2.6)pyridinophane 7 (1.02g, $2.36 \mathrm{mmol}$, $34 \%)$ as an off-white solid. ${ }^{1} \mathrm{H}$ NMR $\left(\mathrm{CDCl}_{3}, 400 \mathrm{MHz}\right): \delta 3.94(\mathrm{~s}, 8 \mathrm{H}), 7.20(\mathrm{~s}, 4 \mathrm{H})$, $7.41(\mathrm{~s}, 2 \mathrm{H}) ;{ }^{13} \mathrm{C} \mathrm{NMR}\left(\mathrm{CDCl}_{3}, 100 \mathrm{MHz}\right): \delta 39.4,124.7,133.2,158.9 . \quad$ Anal. Calcd. for $\mathrm{C}_{14} \mathrm{H}_{12} \mathrm{Br}_{2} \mathrm{~N}_{2} \mathrm{~S}_{2}:$ C 38.91; H 2.80. Found: C 38.61; H 2.84. 


\section{Polymerization}

A typical procedure is as follows. A $30 \mathrm{~mL}$ Pyrex flask was charged with a magnetic stirrer bar, 6,15-dibromo-2,11-dithia[3.3](2.6)pyridinophane 7 (200 mg, $0.46 \mathrm{mmol}$ ), 2,5-dialkoxy-1,4-diethynylbenzene 8a-c (0.46 mmol), $\mathrm{PdCl}_{2}\left(\mathrm{PPh}_{3}\right)_{2}(33.7 \mathrm{mg}, 0.048$ mmol), and CuI (10.4 mg, $0.054 \mathrm{mmol})$. Toluene $(4.0 \mathrm{~mL})$, and $i-\mathrm{Pr}_{2} \mathrm{NH}(2.0 \mathrm{~mL})$, and $\mathrm{PCy}_{3}(15 \%$ in toluene solution, $0.5 \mathrm{~mL}, 0.23 \mathrm{mmol})$ were added. The reaction mixture was stirred at $80{ }^{\circ} \mathrm{C}$ for 48 hours under nitrogen atmosphere. After cooling, the mixture was washed with aqueous $\mathrm{NH}_{3}$, and the organic layer was dried over $\mathrm{Na}_{2} \mathrm{SO}_{4}$. $\mathrm{Na}_{2} \mathrm{SO}_{4}$ was removed, and the solvent was evaporated. The residue was dissolved in a small amount of $\mathrm{CHCl}_{3}$, and reprecipitated from a large amount of $\mathrm{MeOH}$ to give the corresponding polymer 9a-c as an yellowish brown solid.

9a. Yield: $249 \mathrm{mg}, 91 \% . \quad{ }^{1} \mathrm{H} \mathrm{NMR}\left(\mathrm{CDCl}_{3}, 400 \mathrm{MHz}\right): \delta 0.87$ (br, $\left.6 \mathrm{H}\right), 1.31(\mathrm{br}, 8 \mathrm{H})$, $1.44(\mathrm{br}, 4 \mathrm{H}), 1.73(\mathrm{br}, 4 \mathrm{H}), 3.70-4.00(\mathrm{br}, 12 \mathrm{H}), 6.85-7.15(\mathrm{~m}, 4 \mathrm{H}) ;{ }^{13} \mathrm{C} \mathrm{NMR}\left(\mathrm{CDCl}_{3}\right.$, $100 \mathrm{MHz}): \delta 14.1,22.7,25.8,29.2,31.7,39.8,69.4,89.8,92.4,113.4,116.3,123.2$, 132.2, 153.5, 157.6. IR (KBr): $2212 \mathrm{~cm}^{-1}$.

9b. Yield: $242 \mathrm{mg}, 81 \% .{ }^{1} \mathrm{H}$ NMR $\left(\mathrm{CDCl}_{3}, 400 \mathrm{MHz}\right): \delta 0.87$ (br, 6H), 1.29 (br, $16 \mathrm{H}), 1.48$ (br, 4H), 1.82 (br, 4H), 3.80-4.10 (br, 12H), 6.80-7.00 (br, 2H), 7.10-7.18 (br, $4 \mathrm{H}) ;{ }^{13} \mathrm{C} \mathrm{NMR}\left(\mathrm{CDCl}_{3}, 100 \mathrm{MHz}\right): \delta 14.1,22.6,25.8,26.0,29.2,29.3,31.8,39.5,69.5$, $89.8,92.5,113.6,116.8,123.2,132.2,153.6,157.7 . \quad$ IR $(\mathrm{KBr}): 2208 \mathrm{~cm}^{-1}$.

9c. Yield: $332 \mathrm{mg}, 94 \% .{ }^{1} \mathrm{H}$ NMR $\left(\mathrm{CDCl}_{3}, 400 \mathrm{MHz}\right): \delta 0.87$ (br, 6H), 1.24 (br, 32H), 1.47 (br, 4H), $1.78(\mathrm{br}, 4 \mathrm{H}), 3.65-4.10$ (br, 12H), 6.60-7.00 (br, 2H), 7.10 (br, 4H); ${ }^{13} \mathrm{C}$ NMR $\left(\mathrm{CDCl}_{3}, 100 \mathrm{MHz}\right): \delta 14.2,22.7,22.9,26.0,26.2,29.4,29.7,30.3$ (overlapping signals), 31.9, 39.6, 65.6, 89.8, 92.5, 113.6, 116.6, 123.2, 132.2, 153.6, 157.7. IR (KBr): $2212 \mathrm{~cm}^{-1}$. 


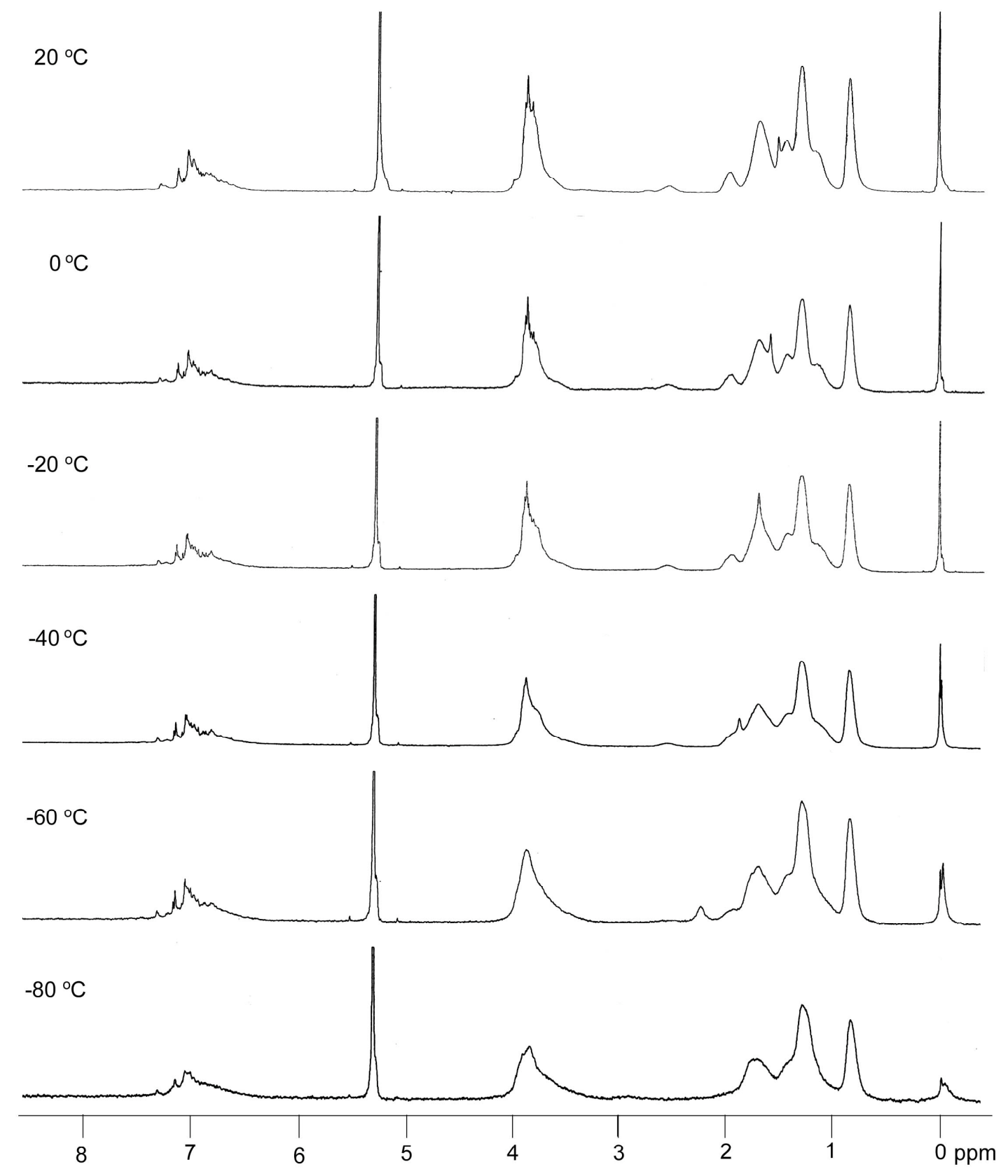

Figure S1. VT ${ }^{1} \mathrm{H}$ NMR spectra of polymer $9 \mathrm{a}$ in $\mathrm{CD}_{2} \mathrm{Cl}_{2}$.

\section{Synthesis of Polymer Complex 10}

To a solution of polymer $9 \mathbf{b}\left(65.6 \mathrm{mg}, 0.10 \mathrm{mmol}\right.$ of pyridinophane units) in $\mathrm{CH}_{2} \mathrm{Cl}_{2}$ $(6.0 \mathrm{~mL})$ was added a solution of bis(benzonitrile)dichloropalladium (II) (39.6 mg, 0.10 mmol) in $\mathrm{CH}_{2} \mathrm{Cl}_{2}(3.0 \mathrm{~mL})$. The reaction mixture was stirred at room temperature for 
24 hours. The product was precipitated from the reaction mixture, separated by filtration, washed with $\mathrm{CH}_{2} \mathrm{Cl}_{2}$, and dried under vacuum to give 10 (74.5 mg, 0.091 mmol, 91\%) as a brown solid. ${ }^{1} \mathrm{H}$ NMR (DMSO- $d_{6}, 400 \mathrm{MHz}$ ): $\delta 0.70$ (br, 6H), 1.15 (br, 20H), 1.67 (br, 4H), 3.98 (br, 5.6H), 4.71 (br, 3.2H), 6.04 (br, 3.2H), 7.20 (br, 2H), 7.50-7.90 (m, 4H). IR (KBr): $2206 \mathrm{~cm}^{-1}$.

\section{Procedure for the Heck Reaction of Halobenzene with Alkene}

In a $10 \mathrm{~mL}$ Schlenk tube was placed the polymer complex $\mathbf{1 0}(0.01 \sim 1.0 \mathrm{~mol} \%$ of the palladium-pyridinophane units) and a stirrer bar. Halobenzene (5.0 mmol), alkene (7.0 mmol), $\mathrm{NEt}_{3}(1.0 \mathrm{~mL})$, and DMF $(4.0 \mathrm{~mL})$ were added. The reaction mixture was stirred at $100{ }^{\circ} \mathrm{C}$. After the reaction, inorganic by-products were precipitated by the addition of $\mathrm{Et}_{2} \mathrm{O}$ and removed by filtration. Products were analyzed by GLC and isolated by column chromatography. All coupling products obtained have already been reported.

\section{Procedure for the Catalyst Recycling Study}

After the reaction, inorganic by-products were precipitated by the addition of $\mathrm{Et}_{2} \mathrm{O}$ and removed by filtration described above. The filtrate was concentrated under reduced pressure, and $\mathrm{CHCl}_{3}$ was added to precipitate the polymer complex 10 . The polymer complex $\mathbf{1 0}$ was retrieved by filtration, dried in vacuo, and used for the next cycle.

\section{References}

1. (a) Takalo, H.; Kankare, J. Acta Chem. Scand., Ser. B 1987, B41, 219. (b) Takalo, H.; Kankare, J. Acta Chem. Scand., Ser. B 1988, B42, 373.

2. (a) Kawashima, T.; Kurioka, S.; Tohda, Y.; Ariga, M.; Mori, Y.; Misumi, S. Chem. Lett. 1985, 1289.

3. (a) Moroni, M.; Moigne, J. L. Macromolecules 1994, 27, 562. (b) Li, H.; Powell, D. 
R.; Hayashi, R. K.; West, R. Macromolecules 1998, 31, 52.

4. Moriguchi, T.; Kitamura, S.; Sakata, K.; Tsuge, A. Polyhedron 2001, 20, 2315. 